\title{
EDITORIAL
}

DOI: http://dx.doi.org/10.1590/So034-759020170601

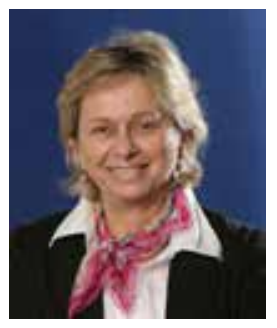

MARIA JOSÉ TONELLI Editor-in-Chief*

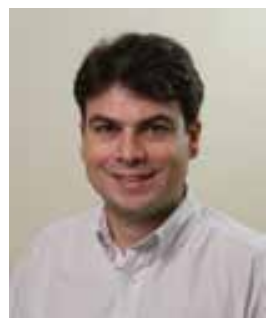

FELIPE ZAMBALDI

Assistant Editor*

\section{On the craft of the editor-in-chief and editorial decisions}

In this last editorial of the year, we would like to address issues that surround and afflict the editorin-chief in his craft. The editor-in-chief is supposed to be the "gatekeeper", with the power to decide whether an article must be published in a journal. However, the word "power" needs to be problematized. What is the real power of an editor? Going over the editorial process: i) the article submitted is evaluated for format and similarities; (ii) after that first evaluation, it is forwarded to the editor-in-chief, who decides if the article must be immediately rejected (desk-reject) or be sent to a science editor in the thematic area of text in question. In the case of $R A E$, many articles are rejected in the screening stage carried out by the editor-in-chief and the assistant editor. However, if the article passes the evaluation process, the editor-in-chief works with his/her colleagues - scientific editors and reviewers - on opinions to improve the article for publication. What is the power of the editor-inchief? Respect the decisions of scientific editors, and work with the reviewers on the assessment and development of the article. Can the editor-in-chief not meet his scientific editors' recommendations? At first, yes, but this could end the evaluation system. If a scientific editor's recommendation is not followed, then why should he continue this task free, to support the academic field? Oftentimes, the editor-in-chief may cling to more than one scientific editor - in the same way as we consult a doctor for a second opinion, at times; but he/she cannot employ such strategy in examining all the articles, except when there is considerable doubt. The editor-in-chief is not a sadist who likes to torture the authors, hoping that they do badly in the process; instead, he/she needs articles. You can say that the editor-in-chief needs articles that can make the journal an interesting research space, where authors and ideas that contribute to the construction of local and universal knowledge found. Texts that may serve as a reference for other studies: this is the nature of academic journals.

In such way, the interest of the editor-in-chief is to publish articles with valuable insights, which can be both theoretical and methodological contributions. Nonetheless, the editor-in-chief depends on scientific editors and reviewers. Clearly, his/her power is not absolute. Are scientific editors and reviewers perfect? No, like any of us, they bring their perspectives, which may have blind spots. This is evident when we consider examination comittees: the student was instructed; and the supervisor performed his job, but the comittee still found numerous aspects, which could not have been anticipated, while going through the text. It is the nature of the scientific work, or better, of human nature, to have limited and partial views.

When are articles immediately rejected? This occurs in three main circumstances: i) the phenomenon has already been researched by several other researchers, and the article in question does not contribute to the field; (ii) the theoretical approach is fragile, and, consequently, the article brings no conceptual contributions; (iii) the methodological procedure is insufficiently described, without reports of the collected data and empirical evidence that support the results. A factor that predates all these is an insufficient literature review. What is the potential contribution of a job when it does not highlight a theoretical gap found in a robust, substantial literature review? These basic criteria are highlighted by expert scientific editors in their area of expertise and reviewers in their assessments. 
Having said that, does knowing the topic immediately make us good reviewers? Not necessarily. Thus, it is essential that in scientific meetings happening in Brazil, we could have more workshops on scientific evaluation process, as we believe that the improvement in this process is continuous and must always be explored and debated in these spaces.

The reviewers' and scientific editors' work is a "quasi-authorship"! They contribute to the academic community, making them fundamental actors. We thank all the scientific editors and reviewers who contributed their time and knowledge to the process of editorial evaluation throughout this year. We could not have published any journal without your generous work. Our deepest thanks.

In this issue, we highlight the "Sociomateriality and the relationship among organizations, artifacts, and practices” forum, organized by Marlei Pozzebon, Eduardo Henrique Diniz, Nathalie Mitev, François-Xavier de Vaujany, Miguel Pina e Cunha, and Bernard Leca. The organizers are internationally acknowledged researchers in this theme, and they present the three articles selected for the forum, contributing toward theoretical and methodological advances in the study of "material turning;" they invite you to the $9^{\text {th }}$ Workshop Organizations, Artifacts, and Practices (OAP), which will take place in São Paulo in 2019.

Two other interesting articles comprise this edition: "Tecnologia da Informação Verde: Estudo à luz da teoria Crença-Ação-Resultado” by Gabriela Figueiredo Dias, Anatália Saraiva Martins Ramos, Rômulo Andrade de Souza Neto, and Evangelina de Mello Bastos; and "Estágios do ciclo de vida e perfil de empresas familiares brasileiras” by Fábio Frezatti, Diógenes de Souza Bido, Daniel Magalhães, and Franciele Beck.

The Perspectives section covers the potential impact of research in business management, with a special contribution by Sérgio Lazzarini in "Pesquisa em Administração: Em busca de impacto social e outros impactos"; and Graziela Dias Alperstedt and Carolina Andion in "Por uma pesquisa que faça sentido". We believe that these two articles promote a desirable and urgent debate for the field of research in business management.

Moreover, this issue features two book reviews: “The perils of doing business across borders" by Oliver Stuenkel and "Cadê meu celular? Uma análise da nomofobia no ambiente organizacional” by Thyciane Santos Oliveira, Lais Karla da Silva Barreto, Walid Abbas El-Aouar, Lieda Amaral de Souza, and Leonardo Victor de Sá Pinheiro. The book recommendations by Belmiro do Nascimento João in "Análise de conteúdo com técnicas quantitativas" and Julio César Bastos de Figueiredo and Caio Giusti Bianchi in "Mapeamento cognitivo" complete the issue.

May the New Year bring further advancement for the research and publications in the field of business management in Brazil.

Enjoy your reading!

Maria José Tonelli and Felipe Zambaldi

* Professors of the Getulio Vargas Foundation, School of Business Administration of São Paulo - São Paulo - SP, Brazil 